\title{
Using films in teaching about Africa
}

\section{Abstract}

This paper begins with a brief critique of didactic approaches to teaching about Africa: such methods do not benefit students pedagogically; they cast Western academy/academics as guardians of truth about Africa; and they cast students as possible receptacles of objective knowledge of Africa. It suggests that an approach based on 'border pedagogy' offers a helpful alternative, and outlines the advantages of using films from/about Africa to achieve this. A Level 3 undergraduate module which incorporates films is outlined, and eight films used in the module are briefly described. Finally, attention is given to students' reactions to the use of films.

Key words: Africa; films; border pedagogy

\section{Introduction}

Since its very first edition, JGHE has given space to articles arguing for the use of film in teaching geography (examples include Aitken 1994; Clark 1977; Gold et al 1996; Jenkins and Youngs 1983). More recently, there have been calls for greater attention to be given to the dilemmas involved in teaching about the Third World (Monk 2000). So far, however, there have appeared no articles in JGHE and very few elsewhere that address the use of film in teaching about the Third World. I argue here that film is a particularly useful resource for teaching about Third World places and people, and in particular for teaching about Africa, although it also presents us with a number of difficulties.

\section{Making connections: an argument for using film in teaching about Africa}

Educationalists have long stressed the importance of building upon students' existing experiences and knowledges, rather than treating them as 'empty vessels' (Dewey 1916). When teaching UK students about Africa (or any other part of the Third World), however, it is unusual to find many students who have any immediate experience of the region(s) they are learning about. Students' apparent lack of prior knowledge about Africa brings with it a number of disadvantages, not least the temptation to resort to 'telling pedagogies' (Freire 1972), wherein the teacher or lecturer presents students with a set of 'facts' and theories, which they learn and reproduce.

Pedagogical arguments against 'telling' or didactic styles of teaching are well rehearsed. Such methods fail to deliver important objectives of any university education, in particular higher order thinking skills. Where students are cast as receptacles of knowledge, rather than as questioning, meaning-making beings (Freire 1972), the scope for developing skills of analysis, criticism and creativity is diminished. Yet, as Monk (2000) argues, geographers should not only be concerned with fostering students' critical thinking skills, important though these are. While not wishing to 
Ansell N (2002) 'Using films in teaching about Africa' Journal of Geography in Higher Education 26(3) 355-368

drive a false dichotomy between our responsibilities to students and to the subjects they study, there is a need also to acknowledge the politics and ethics of representation that we inevitably encounter when teaching about the 'Other'. When the 'Other' is as distant as Africa from First World students' personal experience, the role of the lecturer in framing that representation is particularly significant.

If unable to draw upon students' prior knowledges, however, the lecturer is liable to construct themself (and be constructed by students) as the students' primary and authoritative source of knowledge of Africa. ${ }^{1}$ Teaching about Africa in a university setting inevitably contributes to the construction and dissemination of a set of definitive knowledges. Within any degree course a single geography of Africa is likely to be approved as both necessary and sufficient for the desired level of 'expertise'. While difficult to avoid, this clearly raises questions concerning the right of non-Africans, not only to represent, but to define necessary knowledge of Africa. ${ }^{2}$

Academic validation of an accepted geography of Africa not only casts the university and lecturer in the (unjustifiable) role of arbiters of truth concerning the African continent, but implicitly suggests an objective knowledge of Africa is available to any student who strives sufficiently to acquire it. This disguises the ways in which all knowledges of Africa, including those encapsulated in geography modules, are mediated by the power relations that structure all aspects of our relationship with the continent. This is particularly ironic if a recognition of these power relations is itself part of the 'knowledge of Africa' students are expected to acquire.

Casting Africa as an object of academic knowledge also exacerbates the 'Othering' of African people. Africans exist in students' minds as objects of knowledge: the only apparent connection between 'knower' and 'known' is as subject and object of knowledge. Africans remain as 'distant others', to be appropriated in knowledge schema for the purpose of passing examinations.

In recent years several geographers have argued for what McDowell $(1994,242)$ has described as a transformation of lecturers 'from guardians of truth to directors of conversation'. Rather than students relying on a lecturer as their source of 'correct' academic knowledge, they would build upon their existing knowledges through discussion and critical reading. Cook (2000), in this vein, describes employing 'border pedagogy' (see Giroux 1996; Giroux and McLaren 1994) students engaging with a variety of texts to build upon and develop their situated knowledges about the UK as a multicultural society. Although, as Cook acknowledges, this approach is not unproblematic, it does empower students to critique accepted knowledges, acknowledging their own capacities as makers of meaning.

Border pedagogy, as conceived by Giroux (1992), strives to achieve two things: firstly to unsettle the accepted knowledges promoted through conventional education, and secondly to break down the borders that divide here from there, self from other. Giroux, like Freire, is primarily concerned 
Ansell N (2002) 'Using films in teaching about Africa' Journal of Geography in Higher Education 26(3) 355-368

with the education of those cast as 'Other' through the formal knowledges that conventional education seeks to instil in them. Border pedagogy aims to replace such education with an alternative that empowers its recipients to construct oppositional knowledges.

When teaching about Africa to predominantly white middle class Western students, a different form of border pedagogy is required. While it is desirable that students recognise that academic knowledges about Africa are the constructed outcomes of particular power relations, they should also question their own capacity and entitlement to make meaning about Africa. Border pedagogy rests on students' capacity to transgress 'borders' between themselves and others - to recognise the 'powerfully co-implicated histories of different places and peoples' (Cook 2000: 16). This is difficult where the 'different places and peoples' are very distant, and impossible if students see no point of connection.

Although most students have no 'direct' experience of Africa, they do have a great deal of prior knowledge of Africa. This knowledge may not conform to what lecturers would wish them to know; it may be factually inaccurate and generated through very unequal postcolonial power relations; but it cannot simply be set aside. Nor does it make sense to do so, given those power relations and the enduring influence of stereotypes.

At the same time, it would be wrong to give undue weight to interrogating images that have little to do with the lived experiences of African people. To devote an entire course to deconstructing popular Western images of Africa, while doubtless interesting, would be to ignore the fact that Africa exists, and its inhabitants lead lives that UK students should have some knowledge of. Africa is not so far removed from Western influence that our own or our students' lives have no impact on the experiences of people there. There is every reason to seek to understand the people behind the images - but to do so in a way that acknowledges that we can never know Africa as they do, that our knowledge is inevitably partial, and the product of a range of forces.

What is needed, therefore, is a way of helping students interrogate their own images of Africa: to explore their origins, the ways they reflect historical and contemporary power relations and their relationships to the material circumstances of African people's lives. Film is particularly useful in this regard. ${ }^{3}$ Film plays a constitutive role, not only in the images of Africa available in the West (Eyoh 1999), but also in the production of postcolonial identities within Africa. Many films produced in Africa deal, from a variety of perspectives, with significant social and political issues, and provide an alternative way of introducing these to students. Furthermore, cultural production is itself an element of political and economic structures of African societies and of the broader global political economy. Some advantages of using film are summarised below. 


\section{Using films in teaching about Africa: Rationale}

- Films are a source of some of students' prior images of Africa

- Viewing films is therefore a way of encouraging students to interrogate their own images

- Film is engaging and relatively easy to deconstruct

- Western cinema has produced striking images of Africa, which often exemplify colonial constructions of African people and landscapes

- Film has also been used by African film makers to construct new images of Africa

- Showing such films to students is a way of allowing African voices into Western classrooms while driving home to students the role of the audience and their own experiences in their reading of films

- African cinema, as 'Third Cinema', is generally politically engaged and often addresses social, economic and political issues that are of interest to geographers

- Watching films enables students to understand better how some of these issues are understood and viewed in Africa

- The 'development industry' is also involved in the production of films designed to 'educate' and inform African audiences: such films also often address subjects of interest to geographers, as well as highlighting issues arising from the involvement of Western NGOs in 'development' in Africa

- Documentaries, too, address pertinent issues: it is useful for students to understand that these too are governed by many of the same principles that influence the production of images through fictional films

- Films of all types have been used to manipulate the way people think. They are constitutive in the production of identity and difference

- The political economy of film making reveals a great deal about relationships between the West and Africa, and the impacts of such relationships on cultural production

- This too, strikes a point of connection, enabling students to see a relationship between their own lives and actions and those of people in Africa 


\section{Postcolonial Africa: Representations and 'Realities': a level 3 module}

The remainder of this paper outlines a level 3 module in which films are employed, and students' reactions to it. The module begins with students' existing images of Africa: students work in groups to fill an outline map of Africa with their image(s) of the continent. These images and their possible origins and effects are discussed, in order to get the class thinking about the production and transmission of images. Also in the first week, students are presented with some basic 'factual' information about the continent, and a brief introduction to film theory.

The following eight weeks address particular topics, with a film accompanying each. ${ }^{4}$ More film theory is introduced as required (e.g. in relation to West African films, socially engaged films, documentaries). Some of the films used and the ways in which they are used are presented below. The last two weeks of the module are devoted to debates about issues raised in some of the films. ${ }^{5}$

\section{Selecting the films}

There are an immense range of films which represent Africa: ${ }^{6}$ those discussed here could readily be substituted by alternatives. The particular films used were selected on the basis of several criteria:

- films drawn from a variety of genres

- $\quad$ both Western and African-made films

- films that address issues of interest to geographers

- films which have attracted enough academic attention for students to be able to read critical accounts

Clearly these criteria represent a judgement on the part of the lecturer and are in themselves reflective of the power relations critiqued above. The bases for the selection should therefore be made clear to students. It is also necessary to stress that the idea of the module is not to compare representations against realities but to recognise that representations are products of the material world and have effects in the real world.

The eight films integral to the module are:

- two Hollywood movies

- two examples of francophone West African cinema

- two films made with NGO finance in Zimbabwe 
- one South African documentary

- one Open University video in which a Granada TV documentary series is discussed

\section{The films}

Out of Africa (Pollack, USA 1985), a film many students have previously seen, offers a highly romanticised view of colonial Africa. While it might be argued that Africa is merely presented as a backdrop to an adventure story whose only 'real' characters are white Europeans, this is characteristic of colonial portrayals of Africa wherein African people are either effaced from the landscape, or naturalised within it. In their rust red garments, Maasai people, for example, are presented as just as much a part of the background as the red soil on which they tread. The film's white characters constantly draw attention to ethnic distinctions based on the spurious supposed characteristics of the various Kenyan 'tribal' groups - again reflective of colonial practice.

The film, however, is not a colonial portrayal of colonial Africa. While it reflects elements of the colonial relationship between Kenya and Western Europe in the early twentieth century, it also represents ideas expressed in the 1930s by Danish baroness, Karen Blixen (pen name 1937), as well as the relationship between Hollywood and Africa in the 1980s. Whereas, in her book, Dinesen represents herself as a critic of colonial rule, the film has been accused of casting her as an active participant in colonial subjugation (Cooper 1999; Cooper and Descutner 1996), in order better to fit the understandings and dramatic demands of the 1980s (Luedtke and Pollack 1987). In viewing the film, students can be encouraged to examine which aspects of colonialism the film questions or critiques and which it leaves unquestioned or hidden.

Xala (Sembene, Senegal 1974) addresses themes of cultural change, neocolonialism and the exploitation of the poor by the bourgeoisie, through the fictional story of El Hadji Abdou Kader Beye, a prominent businessman in a newly independent African country (a thinly veiled Senegal). El Hadji chooses from 'traditional' culture and imported Western practices as suits his desires, both practising polygamy and using Evian water to clean his car. When he marries his third wife, but refuses to submit to a traditional ritual which he views as demeaning, he is struck with impotence attributed to a curse or 'xala'. Upon advice he seeks a 'traditional' cure which requires him to perform humiliating rituals. Despite fraudulent business deals, the cost of treatment, along with that of the marriage itself, drives him to bankruptcy. Only through accepting humiliation at the hands of the beggars he has cheated can he be cured.

The film is didactic in intent and heavy on symbolism (see Lyons 1984), the impotence suffered by El Hadji invoking the impotence of Senegal's bourgeois elite when corrupted by neocolonial influence. The Chamber of Commerce, in its mimicking of its French predecessor and continued surveillance by French advisors, stands in for the Senegalese government. Many areas invite 
Ansell N (2002) 'Using films in teaching about Africa' Journal of Geography in Higher Education 26(3) 355-368

discussion, particularly in relation to cultural conflict and the persistence of colonial influence. Sembene's moral tale critiques simplistic dualistic approaches to tradition/modernity, instead advocating a critical approach to both. It further suggests that when the poor act together they exercise considerable agency and can make the elite answerable, although in this regard it differs from Sembene's novel of the same title published a year earlier. It is also interesting to explore the political economy within which the film was produced. Gugler (1998) outlines the contrasts between the film and the book, attributing differences partly to the differing audiences Sembene was seeking to address and partly to compromises made in order to secure funding. He also gives details of the cuts that were imposed when the film was screened in Senegal.

In Packaging Culture (UK 1995) a video accompanying the Open University's 'Third World Development' course, documentary maker Leslie Woodhead and anthropologist David Turton, who collaborated on Granada TV's 'Disappearing Worlds' series of programmes on the Mursi (a small ethnic minority group in Ethiopia), discuss the decision-making processes behind the series. They examine the ways in which anthropological documentary making changed over 20 years, from treating the Mursi as an exotic museum piece in danger of disappearing (thus needing to be preserved on film for posterity) to people with their own voices who are adapting resourcefully to changing circumstances. Students are encouraged also to view the original documentaries, which usefully illuminate the problematic relationships that persist between minority peoples and African states. The sixth programme in the series, produced since the Open University video, and recently screened on Channel 4, True Stories: Fire will eat us, is a much more reflexive documentary, again reflecting wider changes in the ways social scientists research and represent Africa. Packaging Culture raises important questions concerning the representation of Africa to a 'non-specialist' audience, particularly in relation to the 'Othering' of minority peoples, and packaging of African lifestyles for consumption in the West. Besides gaining an insight into the making of documentaries about Africa, students can also be encouraged to analyse the Open University video itself. It is interesting to contrast the video with David Turton's (1992) written exploration of the Mursi documentaries.

The television programme, 7-Up in South Africa (Granada TV, UK/South Africa 1991), was screened on South African television shortly before the first post-Apartheid election. Twenty 7year-olds from a cross-section of South African society talk about their lives, opinions and hopes for the future. While based on an earlier concept (the Granada TV 7-Up series which began in the UK in 1964), the approach of this programme - celebrating diversity among children of varied ethnic, gender, class and geographical backgrounds - nonetheless exemplifies the postmodern use of difference as a nation-building tool in South Africa. (This approach also imbues Desmond Tutu's 'Rainbow Nation' image, and the multicoloured South African flag, unveiled at about the same time.) Television has been an important and contested aspect of South Africa's nation building process in the post-Apartheid era (Barnett 1999; Maingard 1995), and 7-Up exemplifies 
many areas of cultural struggle. Besides exploring children's diverse experiences of Apartheid, the documentary prompts discussion of issues surrounding the practical implementation of multiculturalism in South Africa: notably debates about the depoliticisation of ethnicity, links between language, ethnicity and 'culture' and policies aimed at breaking down boundaries. The use of individuals to 'represent' particular sections of South African society, and associated risks of entrenching identities, also merits discussion.

The film Flame (Zimbabwe 1996) was made in Zimbabwe with a British director (Ingrid Sinclair) and Zimbabwean scriptwriter (Tsitsi Dangarembga) and, according to its California Newsreel jacket, is 'perhaps the most controversial film ever made in Africa'. It concerns the experiences of women combatants in Zimbabwe's independence war, and highlights the failure of postindependence Zimbabwean society to fulfil women's expectations. The film has a clear feminist agenda, and presents African women in a very active and 'non-traditional' light. It has come under fire from many directions: sections of the film were seized by the police under the direction of the Ministry of Information. The film was subsequently banned in Zimbabwe (until changes had been made), ostensibly for showing a rape scene, and denounced as unwelcome Western interference. Much of the pressure behind the ban came from the influential War Veterans' Association who objected to being portrayed as rapists, although the fact that the film was openly critical of the failure of the post-Independence state to substantially improve the condition of rural women can not have helped its case with the ZANU(PF) government. Criticism was not restricted to those with the power of veto over the film's distribution. Flame was regarded by African film critics as too politically correct and too issue based. Margaret Dongo, an independent MP (one of few women in Zimbabwe's Parliament, and a former combatant herself) is critical of the girls' portrayal as motivated more by pursuit of boyfriends than the political cause, and marginalised from strategizing. She also criticises the film's failure to show the full brutality of rape (McCloy 1997). African feminists have criticised the film as the product of a European gaze, and for exaggerating both the heroism and sense of uselessness, thereby portraying the women as victims. Flame can be used to prompt questioning, not only of Western stereotypes of African women, but also of the cultural politics of African feminism, and the right of Western women to represent African women.

Film has been used quite widely in Africa as a way of educating people about AIDS - it is an accessible way of presenting information to people of limited literacy. Everyone's Child (Dangarembga, Zimbabwe 1996) is one such film - made in Zimbabwe to encourage people to view children orphaned by AIDS with sympathy rather than suspicion. The film was made through the Media for Development Trust, with funding from the UK's ODA, and has a rather sentimental plot and didactic approach. Besides dealing with issues surrounding AIDS orphans, the film prompts questions concerning the educational use of film. Particularly worth interrogating is the production of a film by NGOs, funded by, among others, the UK government, to persuade people that the care of AIDS orphans is primarily the responsibility of the community, and not that of 
NGOs. Also noteworthy is the fact that the film is made in English (a response to the need for international distribution), which diminishes both its realism and its accessibility to many of its target audience.

Hyenas (Mambety, Senegal 1992) could not be more different from Everyone's Child. It is an artistic, humorous but ultimately cryptic film, with a soundtrack simultaneously in Wolof and French. The film is based upon Swiss playwright Friedrich Durrenmatt's play, The Visit. It tells of the visit of an elderly, ugly but very rich woman (Linguere Ramatou, 'richer than the World Bank') to a bankrupt town, and the residents' efforts to persuade her to part with her money. She agrees, on condition that she is permitted to buy the court, and require the citizens to carry out a death sentence on the amiable shopkeeper who many years earlier had betrayed her. Many elements of the film can be read as an allegory of the relationship between an African state and the IMF/World Bank - the willingness of the former to destroy itself in order to secure the riches promised by the latter. Linguere Ramatou reveals, for instance, that she has bought up the town's industries, and then closed them down. Mambety explained his choice of the title 'Hyenas', perhaps revealing his view of the culpability of Africa in its dealings with the International Financial Institutions: 'The hyena is an African animal. It is quite singular in its wildness, for it never, so to speak, really kills. In fact, it is a carrion eater. It can sniff and smell the sickness of other animals' (cited in Rayfield 1995, 81).

The last film shown on the module is Steven Spielberg's film, Amistad (USA 1998), which portrays the aftermath of an uprising on a slave ship in 1839. Although Amistad is not set in Africa, it is interesting in its portrayal of Africans, and is a film that students should, by the end of the module, be able to critique effectively. In particular, the clichéd courtroom drama plot, and casting of Americans in the heroic roles is very apparent. (Interestingly a fictitious black American character is invented which allows the film to have a black American on the winning side, while only one of the Africans is vested with an individual character). Slavery is portrayed through the film as a cut and dried issue, resolved through the courts, good winning over bad, with the Amistad incident as the defining moment. Historical accounts tell a different and much more complex story. That the slave leader, Cinque, himself ultimately became a slave trader sits very uneasily against a romanticised and paternalistic plot that suggests he should owe a great debt to his liberal American liberators.

\section{Students' reactions}

There are various ways in which the impacts of a module can be assessed. One is the formal assessment of students' learning. A compulsory exam question asks students' to demonstrate some aspect of the representation of Africa through film: students have generally performed well in 
response to this question. A single examination question cannot, however, provide evidence in relation to all of the aims of using film that were set out in the introduction to this paper, in particular those relating to the development of a 'border pedagogy' whose purpose is to challenge received knowledges and to transgress borders between self and other. The module's impacts, like those of all modules at Brunel, are also assessed through standardised 'module assessment forms'. These have generated largely positive responses, films featuring highly in students' comments (both positive and negative). For a more detailed picture of the part films played in students' experience of the module, they were last year invited to answer the following question: 'In what ways do you think the use of films in this module has made a difference to your understanding of African geographies?' All students responded to the question.

\section{Practical benefits of using films}

A relatively small number of students drew attention to the practical benefits of having seen films during the module - that it made things interesting, added variety, was a change from using textbooks etc. More widely, many students in the module evaluations highlighted the films as something that added interest to the module.

'Using films was good as it broke up the lectures ... '

'Changing between lectures and videos made things more interesting.'

'Good way of involving everyone in discussion.'

'It made it less tedious and prosaic in the sense it provided certain aspects of this continent that a textbook would struggle to present or provide a critical enough analysis or in such a cohesive manner, as a video can.'

\section{Drawbacks}

Not all students were equally satisfied: a minority felt the films were boring or difficult to understand, and even confused the messages they thought they were supposed to be getting from the lectures. This suggests that for some students the films neither captured their interest, nor achieved the purposes for which they were included in the module. There were others, however, who found the films challenging, but nonetheless considered them beneficial in altering their perceptions of Africa.

'Some of the films were very boring and did not help in delivering the messages of the specific topic.'

'Some of the films used were quite out-of-date and hard to get to grips with what they were actually trying to convey.'

'If the film is interesting then it is easier to concentrate than during a lecture, but I think you get more caught up in the general storyline than what it is particularly telling you about Africa eg Amistad.' 
Many students saw films as an (additional and more visual) way of learning what Africa is like. A number qualified this, by referring only to the 'African' films. There was a strong sense among the students that Africa could not be adequately 'known' from a textbook alone, but that a more visual understanding could be achieved through this alternative source of knowledge. Clearly there is a danger here if students adopt an unquestioning approach to the visual images, and imagine that they are 'seeing Africa' through them, but in many cases their responses also suggested an awareness that such images are constructed. One valuable idea that the films conveyed to students was the diversity of Africa, and the inadequacy of any single representation.

'It is useful as it sets the scene, in that you can see how the (sic) Africans live, rather than having to imagine it yourself.'

'With the module covering a continent that many pupils are unlikely to have been too (sic), it was very important to have some visual representations to aid learning and understanding of the topics to be covered.'

'Some films allowed a 'mental' image of what Africa is like, in rural and urban areas, which may help enhance the understanding of Africa as people can 'picture' and 'imagine' what it is like in Africa.'

'The films allow you to see Africa so rather than looking at words on an OHP you can vision Africa and the people.'

'I (sic) has helped me understand how diverse Africa really is and has stopped me thinking of Africa as a whole and as individual countries even more now.'

'The films made the issues more real and less academic.'

\section{Alternative representations of Africa}

A large number of students appreciated the opportunity to view representations of Africa deriving from African sources. This was a key purpose behind the use of films, but once again it poses potential dangers. Some of the students' comments suggested they were taking the films as representative of African views of Africa. It is clearly necessary to ensure that students recognise the role of the lecturer in selecting the films. Suggestions that one can see 'how Africans themselves, see themselves' need to be tempered by a recognition that only a small minority of African's can express themselves through film, and of the differing ways in which films are read by different audiences.

'To show African films which are produced by Africans for an African audience is quite interesting.'

'It gives a balanced understanding of how Africa is perceived from both international and national perspectives. Where as (sic) beforehand the only opinions I had on Africa were from Western sources.'

'The African films gave an insider view of the issues, so rather than just having the lecturers (sic) views you could see how Africans feel about the issues.' 
'It has also helped me understand what issues African people find as important.'

'They have helped to portray a very local answer to some of the topics covered.'

'Also watching films directed by different people ie Hollywood/African shows a wider view point, thus you not only see how Hollywood views Africa but how Africans themselves, see themselves.'

\section{Questioning representations of Africa}

There were other comments that revealed that students were aware of the politics of representation. A number demonstrated an understanding that images of Africa are deliberately constructed. In particular, they contrasted African-made films with those produced in Hollywood, and recognised that decisions were made concerning how Africa should be portrayed.

'I feel that I (sic) has helped me understand African culture, but also helped me understand that what is show (sic) is not always reality.'

'This module has made me question the issues behind the films I see.'

'Understanding how different African film makers make use of an issue compared to 'Hollywood' filmakers (sic) has given me a whole new outlook over the image of Africa. The films allow one to see Africa in a new light - without the "glossyness" of Hollywood'

'Compares Western (Hollywood) and African films allowing you to conclude on ... how each party chooses to portray Africa.'

\section{Preference for documentaries}

Nonetheless, there were a few students for whom fiction films were too distant from 'reality', and who felt that viewing documentaries would have given them a 'better understanding'. This is an interesting issues as it suggests these students were not fully aware of the constructedness and limitations of the documentary form, and were perhaps more willing to 'trust' documentaries as a source of information. Most of the films dealt with 'real life situations', if in fictional form.

'I feel documentaries can also be used to also gain a better understanding of some of the debatable issues covered i.e. Aids, Third World debt. I feel these would have a stronger impact on students who would probably gain a deeper understanding of these issues an how it actually affects the African population.'

'Perhaps more documentaries would be better because they involve real life situations.'

\section{Recognising complexity}

A few students demonstrated a more sophisticated understanding of both the power relations involved in the construction of films and the role of the audience in interpreting them. (Other students may also have been aware of such issues, but did not express this in their answers.) One student, for instance, stressed that documentaries too are constructed. This student also 
questioned the validity of African films as representative of Africa, recognising, rightly, that even films emanating from African film industries are not an authentic African voice, but also a product of Western cinema tradition.

'The use of film will always be important in expressing the cultural beliefs of a country, however as most African nations do not have a film industry a lot of the films used in the module were tainted from European film ideas. ... The documentaries too have an issue of being biased, however this should not undermine the importance of film in being able to capture a moment of cultural importance and they are therefore essential viewing.'

'[They] allow me to interpret the meaning of different aspects in any way I see fit. With text there is usually only one interpretation that can be made. It also shows that there is more than one way to view Africa and its people, and that no single interpretation is correct.'

\section{Conclusions}

The comments of students asked to assess the influence of films in shaping their understandings of African geographies reveal that using films achieved some of the intentions of a 'border pedagogy' approach. The films were a visual stimulus, and encouraged students to interrogate their existing impressions of Africa. To some extent the films themselves critiqued received knowledges of Africa, and where hegemonic representations were used these were readily identified and deconstructed by students. Using films was also seen by students as a way of allowing African 'voices' to be heard in the classroom. This is perhaps one of the more problematic aspects of the use of films. It is necessary to make very clear to students that films are never the straightforward expression of a universal representative African voice, and also that their personal reading of a film will differ from that of members of African audiences. If there is a danger that students will nonetheless take the films as representative of 'Africa', this makes the task of selecting films more important - a task which inevitably falls to the lecturer: it is thus impossible for the lecturer to abdicate their role as 'expert' in shaping 'appropriate' knowledges of Africa.

While the use of films was quite effective in promoting the deconstruction of hegemonic images of Africa, there was perhaps less success in moving towards a 'transgression of borders'. Border pedagogy aims to break down boundaries between 'self' and 'other', and a module about Africa inspired by border pedagogy might therefore intend that students should feel a greater connectedness with Africa, and with African people. While there were a few comments from students about getting an 'insider view' of Africa through the films, and that films helped in 'making the issues more real', most students' responses suggested that they still saw Africa as a distant 'object of knowledge'. Given that most people portrayed in films are fictional, and that 'Third cinema' seldom strives to develop empathy between audience and characters, film alone perhaps cannot promote the breaking down of boundaries. 


\section{Endnotes}

${ }^{1}$ This is not to suggest that all university courses on Africa represent Africa as a set of facts for consumption. Didactic teaching is, however, a temptation that is harder to overcome when teaching about Africa than when teaching about places closer to home.

2 These questions concerning the representation of Africa by Western academics have been discussed elsewhere in relation to research in Africa (e.g. Madge 1994; Sidaway 1992).

${ }^{3}$ Another useful source of images for interrogation is the media, both African and non-African (see Aspaas 1998). The module described here has a coursework assignment which asks students to make use of what they have learned in relation to films in order to deconstruct media representations of particular issues.

${ }^{4} \mathrm{~A}$ key resource that is required for a module in which films are a central component is a suitable timetable. Some of the films shown in this course are $2 \frac{1}{2}$ hours long, which clearly demands a minimum of one three hour slot. Level 3 modules at Brunel are generally taught across a single semester in blocks of two or three hours. This module has worked best when taught on a single day each week, with a one-hour session in the morning, comprising mainly lecture and a threehour slot in the afternoon for the film and related discussion.

${ }^{5}$ This constitutes part of the assessment of the module.

${ }^{6}$ Many African-made films are available through California Newsreel. A useful stockist in London is the African Video Centre (7 Balls Pond Road, Dalston, North London, N1 4AX). Here it is possible to hire or purchase a very wide variety of films relating to Africa.

\section{References}

Aitken, S C (1994) 'I'd rather watch the movie than read the book' Journal of Geography in Higher Education 18(3), 291-307

Aspaas, H R (1998) 'Integrating world-views and the news media into a regional geography course' Journal of Geography in Higher Education 22(2), 211-227

Barnett, C (1999) 'Broadcasting the Rainbow Nation: media, democracy, and nation-building in South Africa' Antipode 31(3), 274-303

Clark, M J (1977) 'Geographical film in Higher Education: some problems of application' Journal of Geography in Higher Education 1(1), 53-60

Cook, I (2000) "Nothing Can Ever Be the Case of "Us" and "Them" Again': exploring the politics of difference through border pedagogy and student journal writing' Journal of Geography in Higher Education 24(1), 13-27

Cooper, B (1999) 'Hegemony and Hollywood: a critique of cinematic distortions of women of color and their stories' American Communication Journal 2(2), http://acjournal.org/

Cooper, B and Descutner, D (1996) "It had no voice to it': Sydney Pollack's film translation of Isak Dinesen's Out of Africa' Quarterly Journal of Speech 82, 228-250 
Dewey, J (1916) Democracy and education: an introduction to the philosophy of education. Macmillan, New York

Dinesen, I (1937) Out of Africa Putnam, London

Eyoh, D (1999) 'Teaching culture and politics with African cinema' in Bastian M L (ed) Great ideas for teaching about Africa Lynne Rienner, London

Freire, P (1972) Pedagogy of the oppressed. Penguin, Harmondsworth

Giroux, H (1996) Living dangerously: multiculturalism and the politics of difference. Peter Lang Publishing, New York

Giroux, H A (1992) Border crossings: cultural workers and the politics of education Routledge, New York

Giroux, H A and McLaren, P (eds) (1994) Between borders: pedagogy and the politics of cultural studies. Routledge, New York \& London

Gold, J R, Revill, G and Haigh, M J (1996) 'Interpreting the Dust Bowl: teaching environmental philosophy through film' Journal of Geography in Higher Education 20(2), 209-221

Gugler, J and Diop, O C (1998) 'Ousmane Sembene's Xala: the novel, the film and their audiences' Research in African Literatures 29(2), 147-158

Jenkins, A and Youngs, M (1983) 'Geographical education and film: an experimental course' Journal of Geography in Higher Education 7(1), 33-44

Luedtke, K and Pollack, S (1987) Out of Africa: the shooting script Newmarket Press, New York

Lyons, H (1984) 'The uses of ritual in Sembene's Xala' Canadian Journal of African Studies 18(2), 319-328

Madge, C (1994) 'Ethics of research in the Third World.' in Robson E and Willis K (eds) Postgraduate fieldwork in developing areas: a rough guide. Developing Areas Research Group, IBG, Monograph 8.

Maingard, J (1995) 'Trends in South Africa documentary film and video: questions of identity and subjectivity' Journal of Southern African Studies 21(4), 657-667

McCloy, M (1997) Dongo vs Flame, Electronic Mail and Guardian, South Africa

McDowell, L (1994) 'Polyphony and pedagogic authority.' Area 26(3), 241-248 
Monk, J (2000) 'Looking out, looking in: the 'Other' in the Journal of Geography in Higher Education' Journal of Geography in Higher Education 24(2), 163-177

Rayfield, J R (1995) '"Hyenas": the message and the messenger' Research in African Literatures 26(3), 78-82

Sidaway, J D (1992) 'In other worlds: on the politics of research by 'First World' geographers in the 'Third World'.' Area 24(4), 403-408

Turton, D (1992) 'Anthropology on television: what next?' in Crawford P I and Turton D (eds) Film as ethnography Manchester University Press, Manchester 